\title{
The Ideas and Countermeasures of Renovation of Joint-stock System in Enterprises
}

\author{
Chen Yanfa \\ (NanChang Institute of Science \& Technology, Nanchang,330108)
}

Keywords: Shareholding; Innovation; Business Administration

\begin{abstract}
As China's market economic system becomes more and more perfect, China's market competition intensifies, and in order to be able to stabilize its own heel and achieve sustainable development, the best solution is the joint-stock reform. The reform of the joint-stock system is the major development trend faced by Chinese companies. It can not only preserve the existing economic strength of the company, but also guarantee the scientificity and reliability of the system. However, there are many drawbacks in the process of reforming the shareholding system. It must be treated in a scientific and rational way. New ideas should be taken to solve the defects, and only then can the company's competitiveness be fundamentally improved.
\end{abstract}

\section{Introduction}

Shareholding system is a popular form of organization and management of the economy in the world today. It will not only help companies raise capital and develop their economies, but it will also help enterprises transform their operating mechanisms and enhance their vitality. However, in the process of reforming the joint-stock system, many companies are still incorrectly aware of the fact that the practice is still unreasonable. As a result, the shareholding system has brought about some negative effects. The first is that it is difficult to turn to understanding. Under the influence of backward consciousness and traditional concepts, regardless of the society or the government, regardless of whether the enterprise or the employee, there are still various incorrect understandings about the transformation of the company's shareholding system; some regard the transformation of the company's shareholding system as the decoration of the enterprise reform, holding The attitude of negative resistance or coping with the situation is still relatively common, and some of them regard the reform of the corporate shareholding system as the introduction and development of capitalism. These incorrect views and understandings are not only a "stumbling block" for the transformation of joint-stock companies, but also a "top door bar" for the healthy development of joint-stock companies. Therefore, this paper studies the reform of the joint-stock system of enterprises, puts forward innovative ideas and countermeasures, and solves the problems encountered in the joint-stock system.

\section{Joint-Stock Enterprise Overview}

The total registered capital of a company limited by shares is composed of the same number of shares and raises capital through the issuance of shares (or equity certificates). The company is legally liable for the company's debt with its entire assets. Its main features are: the company's total capital is divided into equal shares; the shareholders assume limited liability for the company by the shares they subscribe for, the company assumes responsibility for the company's debt with all its assets; each share has a voting right, and the shareholders hold shares, enjoy rights, assume obligations.

The characteristics of joint-stock companies are as follows:

(1)The issuance of stocks as a vouchers for shareholder's shares, on the one hand to obtain dividends, on the other hand to participate in the management of the company;

(2)Establish the internal organizational structure, the shareholders' congress is the highest authority of the joint-stock enterprise, the board of directors is the permanent organ of the highest authority, the general manager presides over the daily production and business activities;

(3)With risk-taking responsibilities, the ownership income of joint-stock enterprises is decentralized, and the operating risks are shared by many shareholders.

(4)Has a strong dynamic mechanism, many shareholders are concerned about the interests of corporate assets from the operating conditions, so that the company's major decisions tend to be optimized, so that corporate development can be built on the basis of the interest mechanism.

Due to the characteristics of a company limited by shares, it has a lot of places in its organization and management that are different from limited liability companies.

(1)Registered capital: also refers to registered paid-in capital, with a minimum limit of RMB 5 million;

(2)Authority: The general meeting of shareholders is composed of all shareholders.

(3)Board of Directors and Manager: This is basically the same as a limited liability company; the chairman of 
the company is the legal representative of the company and the manager is responsible for the company's management and management; at the same time, the directors should be responsible for the resolutions of the board of directors. If the resolution of the board of directors violates laws, administrative regulations or the company's articles of association, causing the company to suffer serious losses, the directors participating in the resolution shall be liable for the compensation of the company.

\section{Problems in the Development of Joint-Stock Enterprises in China}

\section{(1)Congenitally deficient, the direction of development is not clear.}

Since China began to promote joint-stock pilot enterprises in 1992, a number of state-owned enterprises have rushed to the rush to become joint-stock companies due to hurry. At the time, state-owned enterprises still knew very little about the joint-stock system, and there was no clear direction as to how companies would develop after the system reform. Some corporate funds blindly invested, and encountering a project that "has first been talked about" became the criterion at that time. Therefore, arbitrariness in equity investment is very large. Many investment projects have deviated from the investment prospectus of the prospectus. Many projects have not only failed to generate revenue, but have become a burden on the company.

\section{(2)Institutional problems}

The reform of the system is not complete, and the joint-stock enterprises have a problem that they cannot get rid of: the ownership of the right to represent state-owned assets. At present, it is basically the competent departments of enterprises that exercise the right to represent state-owned shares. Thus, the competent department of enterprises has become a major shareholder. The problem is that the competent authority has not yet established a mechanism for exercising management rights under the new mechanism, so that the joint-stock enterprises have returned to the original track. The right to represent state-owned shares has actually become a talisman of administrative management and even administrative intervention. Joint-stock companies still have indicators. Some joint-stock companies also have to pay management fees, and they become the "maternal wife" who has the final say. The company still has no autonomy. Businesses are faced with higher levels more often than they face the market. It is more restricted by local interests and cannot face the whole country.

\section{(3) The equity structure is irrational}

In the process of joint-stock reforms, China's stock companies have undergone incomplete reforms. The phenomenon of equity concentration is widespread. It is mainly controlled by governments at all levels of the country, and this over-concentration of stock rights poses the problem of the ownership structure of state-owned stocks that are "only one big". In China, the efficiency of most corporate governance is not changed due to the absolute holding status of state-owned shares. On the contrary, the higher the proportion of state-owned shares, the worse the efficiency of corporate governance. This makes it impossible for a listed company to achieve an independent and autonomous capacity in establishing a corporate governance structure. Large shareholders have absolute control rights, and the legitimate rights and interests of minority shareholders lack effective protection mechanisms. The general meeting of shareholders cannot play its due role. State-owned stocks are dominating, which will cause the majority of corporate shareholders to infringe on the funds raised by small and medium-sized shareholders to be used preferentially for major shareholder-prone projects. As a result, the decision-making of projects is often the result that the administrative color is more important than the economic and scientific, and the investment risk is increased.

\section{The Countermeasures and Research on the Development and Innovation of Joint-Stock Enterprises in China}

\section{(1)Optimize the ownership structure to prevent "insider control"}

To improve the ownership structure of modern enterprises in China, it is necessary to gradually guide the largest shareholder in the company to reduce the proportion of shares held, optimize the ownership structure, and introduce diversified investors. To create conditions, the state-owned stocks will be lifted, state-owned shares of the company will be reduced, and the issue of "one share only" will be resolved. Improve the board of directors system and establish the core position of the board of directors in internal control. As a link between the owner and the operator, the board of directors must remain relatively independent of the company's controlling shareholders and internal managers. It is necessary to improve the mechanism for the establishment of the board of directors and establish the board of directors as a truly independent institution that exercises rights and assumes responsibilities. Cut the umbilical cord of directors and managers from the personnel configuration to ensure the relative independence of board members. Moreover, both the internal control and the corporate governance attach great importance to the incentive and restraint mechanisms and achieve the best in human resources evaluation.

(2)Improve the structure of the board of directors and strengthen the board of directors in the company

The core position in financial governance improves the independent director system of listed companies. To improve the system of independent directors, four basic mechanisms must be established: 1 . The mechanism for 
selecting and employing independent directors; 2 . The incentive mechanism for compensation; 3 . The mechanism for performance evaluation; 4. The credit evaluation mechanism for independent directors. Strengthen the establishment of the audit committee system for listed companies. As an institutional arrangement for effectively protecting the interests of shareholders within the company, the audit committee has created an environment in which the company's management is supervised, which can effectively prevent the company's management from using untrue financial reports to cover up misbehavior and fraud. And effective control.

\section{(3)Increase supervision and control false accounting information}

The main countermeasures to solve the problem of the false accounting information disclosure and the disclosure of listed companies in China are as follows. Strengthen the governance of listed companies, strengthen their supervision, and improve the corporate governance structure; second, we must improve the company's internal accounting control system, implement strict control over the company's economic activities, standardize financial behavior, in order to ensure the authenticity of accounting information With completeness. Strengthen the external supervision of intermediaries and increase their unregulated governance. At the same time, it is necessary to strictly enforce the law, increase penalties for non-standard information disclosure, and reduce the impact of speculative psychology.

\section{Conclusion}

The current internal control problems of China's stock companies are serious; the enterprise system is not perfect, and the construction of corporate culture has not paid enough attention; at the same time, the problem of financial governance is outstanding; and there are also problems in the disclosure of accounting information of listed companies. These problems are the existence of joint-stock companies. It is necessary to solve the current joint-stock system problem in an innovative way, and it is also the focus of enterprise management.

\section{References}

[1]Cho I G. Trend Analysis of Business Management Indices of Local Public Enterprises in Korea[J]. Genetics, 2010, 24(1):135-1e56.

[2]Anzai K, Niidate Y, Hasezaka S, et al. A Study of Analysis Indicators for Grasping States of Business Management in Small and Medium-Sized Enterprises[J]. Ite Technical Report, 2012, 36(17):25-29.

[3]Chipriyanov M, Galina Chipriyanova. Business Crisis Management and its Impact on the Accounting Policy of Enterprises[J]. Business Management, 2014.

[4]Olena H D. Business process of reputation management of food industry enterprises.[J]. Problems of Economy, 2014(1):223_229.

[5]Nicolau C M. The Management of Business Intelligence: Reality of Enterprises Activity[J]. Social Science Electronic Publishing, 2011.

[6]Leshchuk V, Polinkevych O, Ishchuk L. Strategy of engineering enterprises' business process management in reengineering and redesign[J]. 2015:5.

[7]Ning L, Prevezer M, Wang Y. Top Management Turnover and Corporate Governance in China: effects on innovation performance[J]. Working Papers, 2014.

[8]Koudelková P, Svobodová P. Knowledge creation and sharing as essential determinants of SMEs innovation[J]. International Economics Letters, 2014, 3(1):12-20.

[9]Littleboy B. The ideas of George Shackle and Henry Boettinger[J]. History of Economics Review, 2012, 56(56):71-84

[10]Desatnik D S. Varieties of Capitalism and the Innovation Cluster Environment[J]. Emory University, 2011.

[11]Kato M, Charoenrat T. Business Continuity Management of Small and Medium Sized Enterprises: Evidence from Thailand[J]. International Journal of Disaster Risk Reduction, 2017.

[12]Zhang J F. On the Cultivation of Application Ability of Business Management Talents in Enterprises[J]. Journal of Hubei Correspondence University, 2017. 